\title{
Dissemination of the Archetypal Field of Don Quixote in Camil Petrescu's Work
}

\author{
Odette Arhip ${ }^{1, *}$, Cristian Arhip ${ }^{2}$ \\ ${ }^{1}$ Ecological University of Bucharest, Bd. Vasile Milea nr. 1G, Bucharest, Romania \\ ${ }^{2}$ Grigore T. Popa University of lasi, lasi, Romania \\ *E-mail address: arodettea@yahoo.com
}

\begin{abstract}
The study explores the incidence of Don Quixote-archetypal behavior upon the characters of the novels written by the great Romanian inter-war writer Camil Petrescu. The research is conceptually driven type. Recognizable elements of a concept are searched and identified in the fictional pulp and a volatile field is conceptually electrified. The starting premise is that all myths and traditional stories of the world literature embrace widespread and perpetual topics; they break through in all major artistic works. Basically, some of the defining characteristics of Don Quixote are identified in the conduct of Camil Petrescu's epic heroes: the ideal led to the end; illusory quest for truth, beauty and goodness; selfquery; courage despite the unavoidable risk; delight in being defeated, etc. These similarities are supported by examples and arguments.
\end{abstract}

Keywords: archetype; myth; Don Quixote; literature; novel

\section{INTRODUCTION}

If, in the context of a mythical field of the Romanian ballad (Mesterul Manole), the concept of mitem (the minimal unit of form and content in a myth) has demonstrated its reliability, it is difficult, but challenging to admit and to prove the same efficiency in the structure other fields. Therefore, our intention is to parallel Camil Petrescu's work with those of other writers. Such studies are more difficult to organize according to mythical requirements unlike the folk ballad which has received numerous reviews and analyzes, all of them decoding outlines, patterns and unchangeable motifs (Arhip \& Arhip, 2012; Arhip \& Arhip, 2013). A minimum caution impels us to replace the concept of mitem with archetypal representation. Basically, the concept includes the simplest definition of Jung's archetype. Taking the appearance of fantasies, dreams and obsessions, the archetypal representations acquire an aura of concreteness in the writers' imaginary register. In a comparative approach, the form as means of expressing the archetype remains the same. The content is difficult to represent and it has a diffuse, misty aspect. Perhaps this detail determined Northrop Frye to try to redefine archetype in terms of a symbol based on convention and repetition. Acting as associative groups, the archetype becomes a symbol that communicates only in witting communities from diverse cultural areas knowing and explaining its significance. 
In order to avoid the guilt of exaggerations, we appeal to the term archetypal field which is organized by averaging archetypal representations. For example, the archetypal field of Don Quixote has its origins in the mental and meme components of Camil Petrescu. His former schoolmate, Constant Ionescu, honestly believed that his very organic condition is a kind of Don Quixote mood, this being also his most terrible enemy. A character in the novel Patul lui Procust/The Bed of Procustes/The Bed of Procustes, Ladima, is, in many respects, the Spanish knight himself, forced to live amidst Romanian inter-war realities. This character is the archetypal double of Cervantes' hero and his masterpiece had the privilege of famous interpretations over time (Miguel de Unamuno, José Ortega y Gasset, etc.) being sublimated into the central myth of catholic spirituality in Spain.

Specifically and briefly, Cervantes' Don Quixote is seen by Ortega y Gasset as an ambiguous work oscillating between parody and gravitas. Don Quixote is "a Gothic Christ torn apart by modern anxieties" (Ortega y Gasset, 1973, p. 107). Judging in terms of the opposition action-contemplation, the hero experiences the real world overcoming the stage of visual impressionism. A contemporary of Cervantes, the Spanish philosopher, Francisco Sánchez, stated: "Science is not in books, but in things. A person who is pointing me a thing does not produce a vision for me, but he excites my visual potency to perform an act" (Eliade, 1984, P. 74). From this point of view, he is a wise man, yet impelled by a heroic dementia implying sacrifices for other fellow creatures and observing the principles of Renaissance humanism. The peripatetic knight is considered a European model guided by reason, disposition for thorough discussion and quest for truth (Madariaga 1980: 64). In his speeches, the great ideas of Renaissance rationalism may be found (William Shakespeare, Francis Bacon, Giordano Bruno, etc.). The hero wants to restore the initial human stage eradicating the madness of the world and reviving wisdom (Dumitriu, 1981, pp. 34-35). Erasmus of Rotterdam's work The Praise of Folly offers a philological demonstration for the madness and stupidity that govern the human actions and the institutions. Regarding this masterpiece, the Romanian philosopher P. P. Negulescu wrote many studies and he highlighted Don Quixote's figure: "Under the cap with buffoons' bells worn by the humorous Folly, the worried gaze of Wisdom appears and it anxiously looks for the better interests wished by everyone" (Negulescu 1986, p. 63). Both the ridiculous and great adventures of the knight stand out as a metaphor for humanity fighting to float the Edenic dream and balacing between comedy and tragedy, fulfillment and disaster, solutions and paradox.

\section{ASPECTS OF DON QUIXOTE ARCHETYPAL FIELD IN CAMIL PETRESCU'S WORK}

The nascent statement of Don Quixote archetypal field in the Romanian writer's work belongs to his main character in the novels Patul lui Procust/The Bed of Procustes and Ultima noapte de dragoste, intâia noapte de război/Last Night of Love, First Night of War - Fred Vasilescu. It is an excerpt of an interior monologue of the protagonist when he found out that another male character, Ladima, had left a love letter for the main female personage, Mrs. T., a woman loved by both men; after that Ladima committed suicide: "A windmill is moving into my brains". Two observations are appropriate. The first one refers to a special kind of archetypal slide. Fred becomes the very figure of his suffering friend which is an additional argument for the fact that both characters are masks of the author. The already mentioned loveletter had dramatic tones, but also aspects of lucidity. It allows us to perceive an abulic Ladima who has become a sane man just before his death. He should not have worshiped Emilia during 
his ridiculous life, but Mrs. T. The gesture is significant and calls for a quixotic consideration of the hero because the famous hidalgo lived irrationally, but he ended up with a clear, healthy thinking. The literary critic Tudor Vianu endorsed this opinion: "The final point of Cervantes' story has a significant meaning. Don Quixote lives like a mad man, but he dies like a sane one, admitting his long error and aberration. The return of common sense happens only when his vital spring breaks" (Vianu, 1955, p. 34). We face an archetypal representation of death as a panacea of bizarre mental disorders. The second observation refers to another representation and literary motif - the beloved woman who does not know that she is loved. Either Dulcinea del Toboso or Mrs. T. fits perfectly into the topos "he/she does not know that he/she does not know". This association is also supported by Miguel de Unamuno: "And this gentleman is seeking for his cherish. The image of a beautiful and young peasant, Aldonza Lorenzo, whom he loved, but she did not know that she was loved by him and paid no attention to the hidalgo, became the embodiment of Glory and was called Dulcinea del Toboso" (Unamuno, 1973, p. 168).

The first and obvious explanation for the symmetry Don Quixote-Ladima appears from their incapacity to correctly interpret reality. Both fall victim to great delusions. In a study devoted to the well known Spanish writer, the Romanian literary critic G. Călinescu observed the morbid inability to perceive and interpret facts of life. He hinted to a true crisis of realityconcept. An ideal replaces actuality. Quixote's mistrust towards the perspective of the present is obvious; his imagination builds a utopian vision of the world. It designs on reality distorting it until it is altered. Subjectively, the noble hidalgo creates a world from his point of view, defying reality (Călinescu, 1967, p. 225). The same observations are consistent for Ladima's context. Ladima ignored that Romania was during the phase of capital accumulation (Vlăduțescu, 2004; Siminică \& Traistaru, 2013). He was convinced that recession was a false problem. In his mind, the crisis has another cause: the rulers' tax evasion. He wrote an article with the title Poor circulation showing that a handful of people had indecent huge wealth to the detriment of the majority of population living in poverty.

The rudimentary technology in mining industry squeezed hundreds of millions. Observing this, Ladima did not realize that he had negatively involved the owner of the newspaper, Nae Gheorghidiu. Ladima worked there. Ladima strongly and obstinately believes in economic principles able to be applied only theoretically. Essentially, two utopians meet in the same perspective towards facts. Thus, the two scholastic Don Quixote abdicate at no written rules of chivalry. For them, all women should have a particular fairness. All that means ugly or bad is a priori rejected and regarded as inauthentic. The ugliness is replaced by the chimera of absolute beauty. Thus, during a delirious outburst, Ladima considered that the plain and trivial Emilia, a common actress, would be the perfect model for the masters of the Flemish painting: "Oh, and a wife, a plump white wife as you, with big green eyes, is only Life, brilliantly clean and healthy... like a model for Titian... such as Lavinia, as Emilia... in order to prepare the tea you must have warm sleepers... This, this means to me to dream..." (Petrescu, 1988, p. 140). In their mentality, a gorgeous woman is always and equally a respectable one. In his chivalrous journey, Don Quixote first met two prostitutes. According to his distorted principles, Don Quixote saw them as the most charming creatures: "And the first seen two human beings were two young females who are called hookers and his first heroic adventure took place with those two creatures. But they were for his delight two delicate ladies or two noble princesses in front of the gates of a castle which was in fact a mere inn..." (Unamuno, 1973, p. 83). Ladima proves the same insanity perceiving Emilia as a seraphic creature living in a shinning clean and bright room. In fact, her place is a semi-clandestine brothel. Fred Vasilescu lucidly states the truth: 
"In such a place, you come, and, after you finish, you put the due money under the ash-tray and then you leave very carefully without letting any compromising sign" (Petrescu, 1988, p. 94).

When Don Quixote commands to the lions trainers to open the cages in order to face them, the audience considers him really crazy. The reply of his squire, Sancho Panza, reveals a quality that is the nature of chivalry: "He is not crazy. He is just a brave man!" Ladima proves the same bravery on the terrace of the restaurant At the Mound. He strongly invalided Fred's indelicacy that insulted his imaginary lady love, Dulcinea, although the latter was known as a fierce fighter. In Cervantes' story, the hidalgo is not defeated by lions. He is humiliated by several poor cats biting and scratching him with their claws. "Poor Don Quixote! The lions are afraid of you, but few mates hinder you!" (Unamuno, 1973, p. 305). The brave hero was bewared of running cats, but he faced the uncaged lions. Unamuno's insight helps us to discover another precious archetypal representation. The insignificant fact, seemingly harmless, may become fatal in reality. The most petty and harmless being are the most dangerous and devastating ones. We may remember that Ladima is infact obsessed with Rimbaud's verse: „Des serpents géants dévorés par des punaises”. The main characters of the two novels are heroes and have faultless conducts. But this proves once again a tragic axiom: heroism is overtrusting.

Another archetypal presentation coincident with both heroes is the one called by Unamuno "delight in defeat". Whenever Don Quixote or Ladima felt defeated and humiliated, they started to recite whole poems from various authors or from their creations. In fact, Ladima preferred to compose and to include his new poems in hopeless letters which is the same thing. They perceive their defeats as misunderstandings and look at them with indulgence.

If we accept the fact that Camil Petrescu's nature has a few quixotic features, according to the theory of pluri-perspectivism advanced by Tudor Vianu, G. Călinescu and Nicolae Manolescu, we shall find more characters resembling the Spanish hero of Cervantes. Still, in our opinion, this is the case of an archetypal slide (Vlăduțescu \& Ciupercă, 2013; Păun, 2013; Manolea, 2013). There are times in everyone's life when, overwhelmed by worries or obscure thoughts, each person feels the bizarre sensation of the death getting closer. Regardless of social status you have achieved or your psychic condition, everybody passes into nothingness. The fear and anxiety make you wiser and more lucid guiding you toward intimate knowledge of truth. Fred Vasilescu reached this kind of gnosis that may be located next to thanatos. Unraveling the mysteries of Ladima's death, Fred knew better himself letting loose his disturbing revelation in the undertones from his diary. Unamuno turned about this type of substantial knowledge when he commented upon Don Quixote's multi-folded apparently unjustified melancholic moments.

Finally, one last observation: Camil Petrescu's duelists are reluctant to fight against those who do not know the rules of the game between honor and death. A Prussian officer, one of the characters of the novel Ultima noapte de dragoste, intâia noapte de război/Last Night of Love, First Night of War summarizes very well this idea when he agrees to talk to Stefan Gheorghidiu about war-issues and strategy-art. Ironically, the Romanian army is the only one which does not know the rules of the duel. The cynical connotation deserves attention and a proper recall. "The whole German nation loves war (Vlăduțescu, 2014). Especially, many of the Prussians have all kind of cuts ... and we usually say that it is very dangerous to duel with someone not knowing the rules" (Petrescu 1986: 313). Ignorance, sometimes accompanied by infatuation, is far more dangerous than any enemy you meet in a tournament. This is also the lesson learned by Don Quixote from the books carried always with him.

In our opinion, this the myth of Don Quixote retold by Unamuno and these are the possible similarities between Cervantes' work and the one of the Romanian writer, Camil 
Petrescu. Our contribution has highlighted an archetypal representation of Don Quixote in the representative inter-war Romanian novels. We have found a substantial and rich material in the Spanish author's study and we always had in mind the remark of Mircea Eliade: "Unamuno is the only Spaniard who has managed to offer a new Iberian interpretation to idealism and he has transformed a philosophy into a myth" (Eliade, 1993, p. 217).

\section{CONCLUSION}

Camil Petrescu is the Romanian novelist whose work manifests and brings in many, strong archetypal representations reacting to the mythical paradigm of Don Quixote. Essential items belonging to this worldwide archetype are present in the existential formula of the characters of Petrescu's novels: attending plenary and unconditionally the difficult path toward everybody's ideal; the courage to go all the way; the implacable belief in the victory of goodness beauty and truth; the constancy in commitment, faith and feelings. The present study provides another perspective towards Romanian literature that convincingly and well balanced combine the universal patterns and the national ones.

\section{References}

[1] Borowski A. (a), International Letters of Social and Humanistic Sciences 6 (2013) 86-90.

[2] Călinescu G. (1967). Scriitori străini. București: Editura pentru literatură universală.

[3] Borowski A. (b), International Letters of Social and Humanistic Sciences 7 (2013) 113-118.

[4] Ortegay Gasset J. (1973). Meditaţii despre Don Quijote. Bucureşti: Editura Univers.

[5] Negulescu P. P. (1986). Filosofia Renaşterii. București: Editura Eminescu.

[6] Vlăduţescu Ştefan (2004). Argumentaţia şi demonstraţia, ca moduri de impunere. Craiova: Editura Sitech.

[7] Madariaga S., Secolul XX, no. 7-8-9 (1980).

[8] Arhip Cristian, Arhip Odette, Annales Universitatis Apulensis. Series Philologica (13/1) (2012) 7-36.

[9] Vlăduţescu Ştefan, Ciupercă Ella Magdalena (2013). Next Flood Level of Communication: Social Networks. Aachen: Shaker Verlag.

[10] Bitoleanu Iulian, International Letters of Social and Humanistic Sciences 09 (2014) 116-121.

[11] Moisa M. (2011). Caleidoscop la purtător. Craiova: Editura Aius.

[12] Păun Mihaela Gabriela, International Journal of Education and Research 1(10) (2013).

[13] Traistaru Aurelia, Jokull Journal 63(9) (2013) 125-135.

[14] Pretorian Cristina, Ionescu Dan, International Letters of Social and Humanistic Sciences 9 (2014) 49-56.

[15] Eliade M., Revista de istorie şi teorie literară 4 (1984). 
[16] Dumitriu A. (1981). Cartea întâlnirilor admirabile. București: Editura Eminescu.

[17] Smarandache Florentin, Vlăduţescu Ştefan (2014). Neutrosophic Emergences and Incidences in Communication and Information. Saarbrucken: LAP Lambert Academic Publishing.

[18] Eliade M. (1993). Insula lui Euthanasius. Bucureşti: Editura Humanitas.

[19] Vlăduțescu Ștefan (a), Jokull Journal 63(9) (2013) 301-318.

[20] Arhip Cristian, Arhip Odette, Buletinul Stiintific al Universitatii Mihail Kogalniceanu 22 (2013) 107-116.

[21] Manolea Daniela, International Letters of Social and Humanistic Sciences 6 (2014) 55-59.

[22] Vlăduţescu Ştefan (b), Jokull Journal 63(8) (2013) 186-197.

[23] Siminică Marian, Traistaru Aurelia, International Journal of Education and Research 1(12) (2013).

[24] Borowski A. (c), International Letters of Social and Humanistic Sciences 4 (2013) 70-74.

[25] Dima Ioan Constantin, Vlăduţescu Ştefan (2012). Persuasion elements used in logistical negotiation: Persuasive logistical negotiation. Saarbrucken: LAP Lambert Academic Publishing. Dima, IC \& Vladutescu, Stefan (2013a). Some Consequences of the Negative Journalistic Communication in the Austerity Period. Science Series Data Report, 5(7), 2-7.

[26] Unamuno M. de (1973). Viaţa lui Don Quijote şi Sancho. Bucureşti: Editura Univers.

[27] Vlăduțescu Ștefan (c), International Letters of Social and Humanistic Sciences 7 (2014) 8-13.

[28] Vianu T. (1955). Cervantes. Bucureşti: ESPLA,

[29] Nowicka-Scowron M., Dima I. C., Vlăduţescu Ş., International Journal of Management Sciences and Business Research 1(8) (2012) 27-35.

[30] Grecu L. M., Păun M. G., European Journal of Humanities and Social Sciences 28(1) (2013).

[31] Vlăduțescu Ștefan, Mitteilungen Klosterneuburg Journal 64(1) (2014). 